\title{
Heart of glass: spicule armament and physical defense in temperate reef sponges
}

\author{
A. M. Ferguson, A. R. Davis* \\ Institute for Conservation Biology and School of Biological Sciences, University of Wollongong, Wollongong, \\ New South Wales 2522, Australia
}

\begin{abstract}
Siliceous inclusions play an important role in deterring terrestrial herbivores, but their role in marine systems remains controversial. Sponges are ubiquitous members of marine benthic communities and represent a potentially valuable food source for many predatory species, yet they have few natural predators. An in situ method was used to assess the deterrent effects of siliceous spicules or whole sponge skeleton, which were hypothesised to act as a physical defense in temperate reef sponges. Natural concentrations of spicules from 5 species of sponge and the spongin skeleton from a sixth species were incorporated into artificial diets, which were similar in nutritional quality to the sponge tissues. These were offered to the sea urchin Centrostephanus rodgersii in feeding choice experiments including control discs containing no spicules or spongin skeleton. Spicules from 4 species, Tedania anhelans, Clathria pyramida, Chondrilla australiensis and Chondrilla sp., deterred feeding by C. rodgersii. Spicules from a fifth species, Callyspongia sp., and intact skeleton isolated from Cacospongia sp., failed to deter C. rodgersii. This is the first demonstration of antifeedant activity associated with skeletal elements against sea urchins. Importantly, unlike previous work in the tropics, very small spicules (microscleres) measuring $<100 \mu \mathrm{m}$ were effective feeding deterrents.
\end{abstract}

KEY WORDS: Antifeedant activity $\cdot$ Benthic invertebrates $\cdot$ Centrostephanus rodgersii $\cdot$ Physical defense $\cdot$ Porifera $\cdot$ Spicules $\cdot$ Spongin fibres $\cdot$ Urchin grazing

\section{INTRODUCTION}

Sessile organisms cannot actively avoid being eaten. Therefore, they must defend themselves in other ways. Deterring predators with the use of physical defenses is one viable option for many species (Karban \& Myers 1989, Myers \& Bazely 1991). In terrestrial systems, for example, siliceous phytoliths within members of the Poaceae (grasses) have been shown to act as an important physical defense against herbivory (McNaughton et al. 1985). Silica deposited within plant tissues is likely to cause mouthpart abrasion in herbivores and protect particularly vulnerable plant tissues (Sangster 1970, McNaughton et al. 1985). In addition, silica is present in morphological types likely to enhance mouthpart abrasion (Jones \& Milne 1963). Effects on herbivores may be considerable; silicified grasses have been associated with accelerated tooth wear in sheep
(Baker et al. 1959), oesophageal cancer (O'Neill et al. 1980, 1982) and silica urolithiasis (Whiting et al. 1958).

In the marine realm, physical elements can be found in several phyla, but their antifeedent role remains unclear. Among cnidarians, field and laboratory assays have shown a defensive role for calcitic sclerites against both generalist and specialist predators for some taxa (Harvell et al. 1988, Koh et al. 2000). On the other hand, assays of 32 Caribbean gorgonian species failed to reveal significant antifeedant activity of sclerites for 30 taxa (O'Neal \& Pawlik 2002). In some instances the same species have been tested with contradictory outcomes (Harvell et al. 1988, O'Neal \& Pawlik 2002). Perhaps discrepancies arise from the use of gravimetric versus volumetric preparations of feeding materials. On balance, it would appear that sclerites in cnidarians play a minor defensive role. Nevertheless, in some taxa physical defenses may play as 
important a role as chemical defenses in an organism's ability to deter predators. For example, Van Alstyne \& Paul (1992) demonstrated that sclerites from the sea fan Gorgonia ventalina were as important as crude organic extracts in reducing feeding by the predatory gastropod Cyphoma gibbosum, and slightly more effective than extracts at reducing feeding by fish.

Some ascidian taxa also contain physical elements; several contain stellate calcareous spicules and are also chemically rich (Davis \& Bremner 1999). Two studies have contrasted chemical and physical defenses in ascidians. Both report significant antifeedent activity associated with secondary metabolites, at least against fish predators, but no deterrent effect of spicules (Lindquist et al. 1992, López-Legentil et al. 2006). López-Legentil et al. (2006) note that their feeding trials may be conservative, as spicules were spread evenly though their artificial food, whereas in living animals the spicules were concentrated around the zooids.

The skeletal elements of the demosponges, namely inorganic siliceous spicules and spongin skeleton, are known to play a primary role in colony support (Bergquist 1978); however, their defensive role has often been debated (Bowerbank 1864, Uriz et al. 2003). Siliceous spicules have been hypothesised to provide physical defense by irritating the mouthparts and guts of predators (Randall \& Hartman 1968). They have also been shown to penetrate the tissues of vertebrate and invertebrate predators when fed upon (Meylan 1988, Birenheide et al. 1993). Birenheide et al. (1993) suggested that such injuries would leave the predators susceptible to bacterial infection. More recently, Hill \& Hill (2002) reported that a tropical sponge increased spicule concentration in response to simulated predation. In light of these past findings, and given that siliceous spicules in sponges are similar in size, morphology and concentration to the sclerites within tissues of cnidarians (Chanas \& Pawlik 1995), it was therefore surprising that sponge spicules did not appear to deter predators (Chanas \& Pawlik 1995, 1996, Waddell \& Pawlik 2000a,b). Only recently has evidence of spicules defending tropical sponges from reef fish been reported (Burns \& Ilan 2003); the deterrent effect of spicules was positively correlated with their size. Hill et al. (2005) also provided evidence that spicules deterred hermit crabs from feeding on temperate zone sponges, and again spicule size appeared important. The extent to which these physical defenses are effective against other reef inhabitants and their efficacy in other geographical regions remains to be investigated.

Previous studies investigating the effect of sponge spicules in deterring predation focused primarily on predatory reef fish (Chanas \& Pawlik 1995, 1996, Burns
\& Ilan 2003), which are thought to be the principal consumers on tropical reefs (Bakus 1964, Hixon 1983). On subtidal reefs in New South Wales, Australia, the large sea urchin Centrostephanus rodgersii is the most conspicuous consumer, and occurs in densities up to $22 \mathrm{~m}^{-2}$ (Underwood et al. 1991, Andrew \& Underwood 1993), with biomass (wet weight) frequently exceeding $2 \mathrm{~kg} \mathrm{~m}^{-2}$ (Davis et al. 2003). Grazing by this species removes virtually all macroalgae, leaving a substratum covered almost exclusively by crustose coralline algae (the barrens habitat). Hence, they have a major influence on habitat structure (Fletcher 1987, Andrew 1993, Andrew \& Underwood 1993). In addition to algae, $C$. rodgersii consumes sponges, as spicules have been observed within their guts (Wright et al. 1997). Wright et al. (1997) found that chemical extracts from 3 species of temperate reef sponges present in the barrens habitat were successful in deterring feeding by $C$. rodgersii; however, several other species showed no evidence of chemical defense against this predator. We reasoned that these species must have some other form of defense in order to persist in the barren habitat, and we tested the hypothesis that the skeletal elements of temperate reef sponges, when assayed in artificial diets of a nutritional quality similar to sponge tissues, deter feeding by C. rodgersii. Furthermore, we targeted temperate sponge species that differed markedly in spicule size and morphology in order to evaluate the positive correlation between spicule size and predator deterrence reported by Burns \& Ilan (2003).

\section{MATERIALS AND METHODS}

Study species. The deterrent abilities of skeletal elements from 6 sponges were examined. Five of these differed in their spicule size and morphology: Tedania anhelans (Lieberkühn), Clathria pyramida (Lendenfeld) and Callyspongia sp. possessed megascleres and microscleres. In contrast, only microscleres were present in the remaining species, Chondrilla australiensis (Carter) and Chondrilla sp. (Table 1). With the exception of the mound-forming Callyspongia sp., these species were all relatively thin and encrusting. The sixth species, Cacospongia sp., forms fan-shaped colonies that are composed of a skeletal matrix of reticulate spongin fibres (Fig. 1). The spicule size and morphology reported here (Table 1) is derived from microscopic examination of these sponge tissues and with reference to appropriate literature (Hooper \& Wiedenmayer 1994). All species are commonly encountered in urchin-barrens habitat.

Sponge collection. Tissues from colonies of all 6 species of sponges were collected in shallow subtidal 
regions, 10 to $15 \mathrm{~m}$ deep, at each of 3 sites near Wollongong, New South Wales, Australia. Two sites were located at Bass Point, $\sim 25 \mathrm{~km}$ south of Wollongong: the gravel loader ( $34^{\circ} 29.6^{\prime} \mathrm{S}, 150^{\circ} 53.1^{\prime} \mathrm{E}$ ) and 'The Gutter' $\left(34^{\circ} 35.7^{\prime} \mathrm{S}, 150^{\circ} 54.3^{\prime} \mathrm{E}\right)$. The third site, Flinders Islet $\left(34^{\circ} 21.4^{\prime} \mathrm{S}, 150^{\circ} 55.8^{\prime} \mathrm{E}\right)$, was situated $\sim 1.5 \mathrm{~km}$ east of Port Kembla harbour. Palumbi (1986) demonstrated that wave force can influence the size and density of sponge spicules; all our collection sites faced north, away from the predominant SE swell, and so experienced similar levels of wave exposure. Collections of each sponge were made in urchin-grazed barren habitats. On returning to the laboratory, samples were rinsed thoroughly in seawater, and forceps were used to remove all visible extraneous material. Following volumetric determinations (see 'Feeding assays'), samples were immediately stored in a freezer at $-20^{\circ} \mathrm{C}$ until they could be used for nutritional quality analysis and isolation of spicules or whole sponge skeleton.

Isolation of skeletal elements. Frozen sponge tissue was thawed and dried to a constant weight at $80^{\circ} \mathrm{C}$ in an oven with strong air circulation. Spicules were obtained by placing small amounts of dried sponge tissue into the bottom of test tubes ( $25 \mathrm{~mm}$ diameter) and covering the samples with concentrated nitric acid $(70 \% \mathrm{w} / \mathrm{w})$. The samples were left overnight, after which they were heated at $65^{\circ} \mathrm{C}$ in a water bath for 4 to $5 \mathrm{~h}$, until they were a clear yellow colour. The test tubes were then filled with distilled water, and spicules were left to settle to the bottom. The solution was carefully decanted and replaced with distilled water for a total of 4 to 5 rinses to remove all acid residue. Spicules were then flushed into pre-weighed glass trays, and dried to a constant weight at $80^{\circ} \mathrm{C}$. Spicules were obtained from the entire sponge. Each species was homogeneous, with no demarcation between the interior or exterior tissues; nor were there any obvious differences in spicules from different portions of these sponges.

Whole skeleton was isolated from Cacospongia sp. by placing dried sponge tissue into the bottom of a beaker, and covering the sample with $2.5 \mathrm{M} \mathrm{NaOH}$ for a period of $2 \mathrm{~h}$. The spongin skeleton was rinsed thoroughly in distilled water, and dried to a constant weight at $80^{\circ} \mathrm{C}$.

Nutritional quality analysis. Frozen sponge tissue was thawed, and dried to a constant weight at $80^{\circ} \mathrm{C}$. Samples were then ground using a mortar and pestle. The energy content of sponges was determined by combustion of ground samples in a Gallenkamp automatic adiabatic bomb calorimeter. Ash content for the 5 species of siliceous sponges, Tedania anhelans, Clathria pyramida, Chondrilla australiensis, Chondrilla sp. and Callyspongia sp., was determined as the amount of inorganic material remaining after combustion of ground samples. Ash was assumed to be all silica, as in previous studies that have measured the spicule content of demosponges (Dayton et al. 1974,

Table 1. Morphology and spicules or nature of skeleton for the 6 species of demosponges used in feeding assays with the sea urchin Centrostephanus rodgersii. Drawings of representative spicule types are indicated for each species

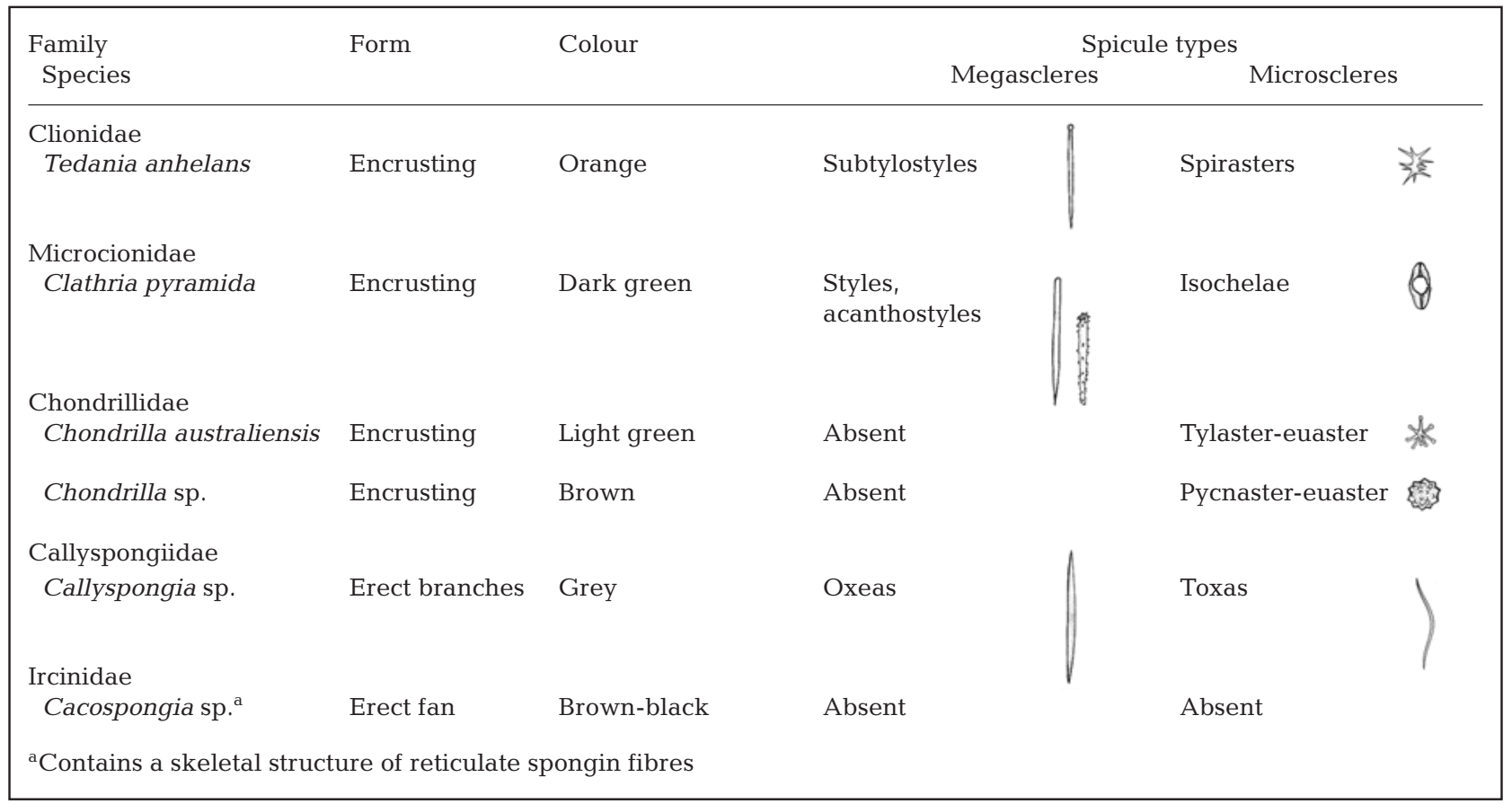




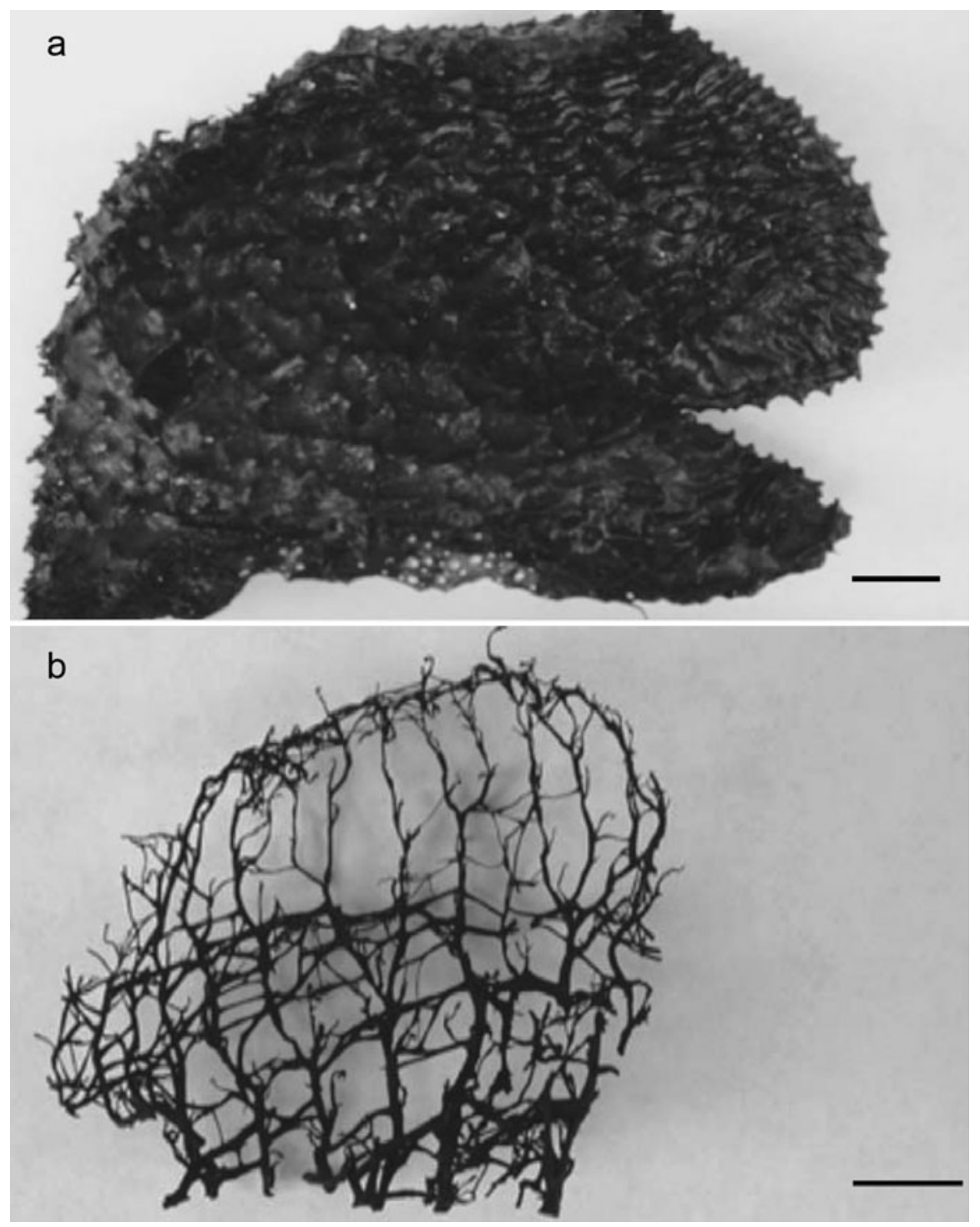

Fig. 1. Cacospongia sp. (a) Erect fan of the sponge removed from the water and (b) the reticulate spongin fibre skeleton. Scale bars $=1 \mathrm{~cm}$

McClintock 1987, Chanas \& Pawlik 1995). Furthermore, microscopic examination of the inorganic material of the 5 spiculate sponges used in the present study revealed that silicate spicules were the primary inorganic constituent. Soluble protein was measured spectrophotometrically following homogenisation of sponge tissue in $50 \mathrm{mM}$ phosphate buffer and $1 \%$ Triton X-100. Dried sponge material was cut into small pieces and placed in 50 volumes of buffer for $3 \mathrm{~min}$. The sample was homogenised with an Omni-mixer (Sorvall) and left to steep for a further $30 \mathrm{~min}$. The sample was homogenised a second time with a Polytron (Brinkmann Instruments) to reduce the remaining small pieces to particles. Protein was then solubilised by combining the homogenate $(100 \mu \mathrm{l})$ with $10 \mathrm{M}$ urea $(387 \mu \mathrm{l})$ and ice acetic acid $(13 \mu \mathrm{l})$ and protein content determined using the bicinchoninic acid (BCA) method of Smith et al. (1985).

Feeding assays. Feeding assays were modified from the in situ methods used for Centrostephanus rodgersii by Steinberg \& van Altena (1992) and Wright et al. (1997). Trials were conducted by feeding $C$. rodgersii palatable agar discs that were similar in energy and protein content to the mean energy and protein content of the 6 species of temperate reef sponges used in feeding assays (Table 2). Each disc consisted of $\sim 3 \mathrm{~g}$ wet weight of the green alga Ulva lactuca, $\sim 0.5 \mathrm{~g}$ agar (Oxoid code no. CM3), $1 \mathrm{~g}$ prawn tissue and $\sim 18 \mathrm{ml}$ 
Table 2. Energy and soluble protein content of the artificial diet used in feeding assays and of sponge tissue given to the sea urchin Centrostephanus rodgersii. Values for individual species and feeding discs represent means $( \pm$ SE) from triplicate analyses $(n=3)$. Values for overall sponge tissue represent means $( \pm \mathrm{SE})$ of the 6 species used in feeding assays. na = not available

\begin{tabular}{|lrcc|}
\hline Diet & $\begin{array}{c}\text { Energy } \\
\left(\mathrm{kJ} \mathrm{g}^{-1}\right)\end{array}$ & $\begin{array}{c}\text { Energy } \\
\left(\mathrm{kJ} \mathrm{ml}^{-1}\right)\end{array}$ & $\begin{array}{c}\text { Soluble protein } \\
\left(\mathrm{mg} \mathrm{ml}^{-1}\right)\end{array}$ \\
\hline Chondrilla australiensis & $17.8 \pm 0.12$ & $1.66 \pm 0.02$ & $14.2 \pm 0.3$ \\
Tedania anhelans & $14.3 \pm 0.38$ & $3.33 \pm 0.09$ & $47.3 \pm 4.8$ \\
Chondrilla sp. & $13.6 \pm 0.42$ & $4.32 \pm 0.13$ & $27.5 \pm 1.2$ \\
Cacospongia sp. & $13.4 \pm 0.53$ & $3.79 \pm 0.18$ & na \\
Clathria pyramida & $13.2 \pm 0.91$ & $2.07 \pm 0.17$ & $18.6 \pm 0.6$ \\
Callyspongia sp. & $5.9 \pm 0.07$ & $0.54 \pm 0.01$ & $6.8 \pm 0.3$ \\
Overall mean sponge tissue & $13.0 \pm 1.95$ & $2.64 \pm 0.37$ & $22.9 \pm 6.9$ \\
Feeding discs & $9.6 \pm 0.06$ & $0.88 \pm 0.09$ & $13.1 \pm 0.2$ \\
\hline
\end{tabular}

$200 \mathrm{~mm}$, and were covered in stiff plastic mesh $(10 \times 10 \mathrm{~mm})$.

Urchins were placed in tubs 3 to $6 \mathrm{~d}$ prior to their use in a feeding trial to allow them to become accustomed to captivity. They were then presented with a choice of 2 pre-weighed discs, 1 treatment and 1 control. The trial was allowed to run for $24 \mathrm{~h}$. At the end of each trial, discs were collected and blotted dry with a paper towel. They were then weighed to determine the amount consumed. The change in mass of discs due to dissolution, absorption, abrasion or other autogenic factors was monitored during all experiments by placing 2 to 3 discs in seawater. Treatment discs contained spicules or whole sponge skeleton at natural concentrations and control discs contained no spicules or spongin skeleton. U. lactuca was collected from intertidal rock platforms on the day of the trials to ensure that it was fresh. It was blended with the prawn tissue and seawater until it was a liquid. Agar was dissolved in seawater at $6.5 \%$ $\mathrm{w} / \mathrm{v}$ and boiled in a microwave for $2 \mathrm{~min}$ until it was clear. When the agar had cooled to $\sim 45^{\circ} \mathrm{C}$, the blended solution was added and the mixture shaken. For treatment discs, spicules were added and stirred evenly throughout the mixture. The mixture was then poured into Petri dishes ( $\sim 54 \mathrm{~mm}$ diameter) to a thickness of $\sim 10 \mathrm{~mm}$, the same thickness as the encrusting sponges (Wright et al. 1997). For assays with sponge skeleton, isolated whole skeleton was cut into pieces the same diameter as the Petri dishes, and embedded into the discs by pouring the mixture through the interstices of the skeleton. Numbered stainless steel washers ( 13 g) were incorporated into the discs to give negative buoyancy and allow identification. Discs were allowed to set for 10 min before being taken out of their moulds and weighed.

As sponges are consumed on a volumetric basis, and not as a dry mass (Chanas \& Pawlik 1995), treatment discs contained volumetrically equivalent concentrations of spicules or whole sponge skeleton as that found in sponge tissues. Volumetric concentrations were determined by displacement of wet sponge tissue into a graduated beaker containing a known amount of seawater. The total volume of the food mixture was determined prior to addition of spicules from an equivalent volume of sponge tissue.

Experiments were done by placing urchins of similar size $(\sim 100 \mathrm{~mm}$ test diameter $)$ into $23 \mathrm{l}$ plastic tubs (Nally Plastic cat. no. 1H049). These were bolted to the substratum in water 3 to $4 \mathrm{~m}$ deep near the gravel loader at Bass Point. The tubs were $448 \times 391 \times$ control tubs with no urchins; changes in mass were consistently low, with the weight of the discs increasing by 3 to $9 \%$. All experiments were conducted during autumn and winter $\left(16\right.$ to $\left.20^{\circ} \mathrm{C}\right)$ and in calm sea conditions.

Statistical analysis. Feeding trials were analysed using a 1-tailed paired $t$-test. The amount of each disc consumed as a percentage of the initial weight was measured, and the proportion of control discs consumed was compared to the proportion of treatment discs consumed. Trials in which $<5 \%$ of both treatment and control discs had been consumed were excluded from the analysis. All disc weights were corrected for autogenic change.

\section{RESULTS}

Spicules from 4 of 5 species of temperate reef sponges reduced feeding by Centrostephanus rodgersii relative to controls, when assayed in artificial diets of similar nutritional quality to the sponge tissues (Fig. 2). At natural concentrations, spicules from Tedania anhelans $(t=1.89,7 \mathrm{df}, \mathrm{p}=0.001)$, Clathria pyramida $(t=1.94,6 \mathrm{df}, \mathrm{p}=0.006)$ and Chondrilla australiensis $(t=1.83,7 \mathrm{df}, \mathrm{p}=0.002)$ significantly deterred feeding. Spicules from Chondrilla sp. did not significantly deter feeding $(t=1.86,8 \mathrm{df}, \mathrm{p}>0.1)$; however, they did cause a reduction in the mean amount of treatment discs consumed, relative to control discs. In contrast, spicules from Callyspongia sp. $(t=1.89,7 \mathrm{df}$, $\mathrm{p}>0.2$ ), and whole sponge skeleton isolated from Cacospongia sp. $(t=1.86,8 \mathrm{df}, \mathrm{p}>0.4)$ did not reduce feeding by $C$. rodgersii (Fig. 2). In the trials with Cacospongia sp., the urchins did not consume the spongin skeleton, but rather grazed the artificial diet from its surface. We repeated the feeding trial with spicules from Callyspongia sp. with a near-identical 

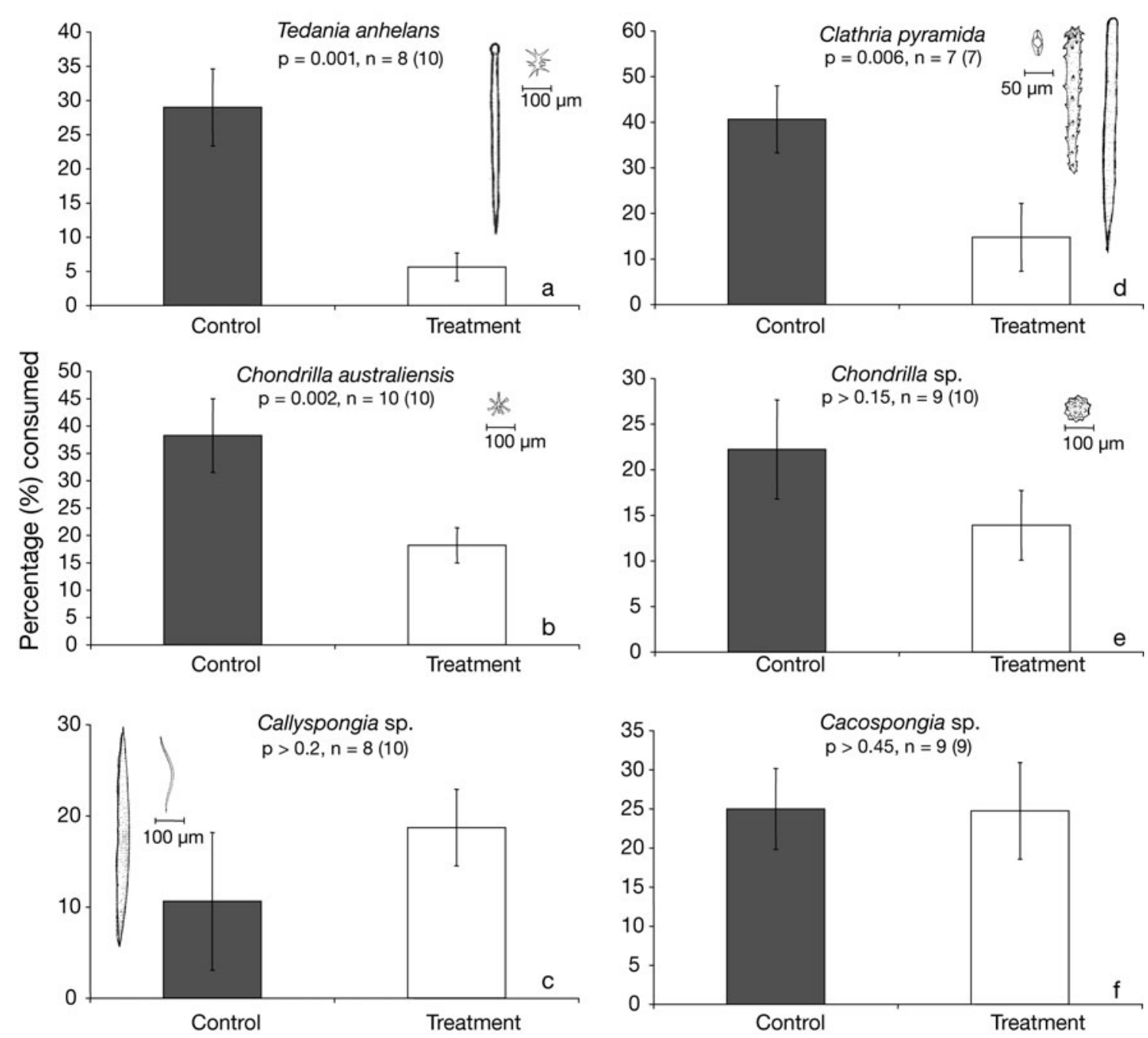

Fig. 2. Centrostephanus rodgersii. Percentage consumption of artificial feeding discs (choice of control or treatment) offered to the sea urchin in an in situ feeding assay. Treatment discs contained natural concentrations of spicules or whole skeleton of (a) Tedania anhelans, (b) Chondrilla australiensis, (c) Callyspongia sp., (d) Clathria pyramida, (e) Chondrilla sp. and (f) Cacospongia sp. Error bars = 1 SE. $\mathrm{n}=$ number of paired treatment and control discs used in statistical analysis (number of pairs deployed in parentheses). Probability calculated using a 1-tailed paired $t$-test. Drawings of representative spicule types are indicated for each species

result; on average more of the treatment discs were consumed $(22.8 \pm 3.1 \%$ [mean $\pm \mathrm{SE}])$ than the controls $(19 \pm 5.9 \%)(t=0.41,8 \mathrm{df}, \mathrm{p}>0.34)$, confirming that this species lacked feeding deterrence.

We did not find evidence of a relationship between the quantity or size of spicules and their ability to deter urchins in our trials. Indeed, Chondrilla australiensis possessed the smallest spicules $(80 \mu \mathrm{m}$ tylasters) and the lowest spicule content $\left(5.4 \mathrm{mg} \mathrm{ml}^{-1}\right.$ live sponge), yet reduced grazing in the treatments by around $50 \%$ (Table 3, Fig. 2). In contrast, Chondrilla sp. had one of the highest concentrations of spicules (23 mg ml-1 live sponge) and Callyspongia sp. had the largest spicules of the sponges we sampled $(725 \mu \mathrm{m}$ oxeas), yet neither significantly deterred urchins from feeding.

Energy content of the sponges we sampled were generally within the range 1.5 to $4.5 \mathrm{~kJ} \mathrm{ml}^{-1}$, with the exception of Callyspongia sp., which was less than a third of the lowest values. Callyspongia sp. also possessed the lowest soluble protein value $(6.8 \pm 0.3 \mathrm{mg}$ $\mathrm{ml}^{-1}$ ), around a quarter of that seen for sponges with the highest values. The addition of prawn tissue to our feeding discs brought the energy and soluble protein values to within the range observed in the living sponges of interest (Table 2). 
Table 3. Maximum spicule length and spicule or skeleton dry weight for the 6 species of temperate reef sponges used in feeding assays with the sea urchin Centrostephanus rodgersii. na $=$ not applicable (lacks spicules)

\begin{tabular}{|c|c|c|c|}
\hline Sponge species & $\begin{array}{l}\text { Maximum } \\
\text { spicule } \\
\text { length }(\mu \mathrm{m})\end{array}$ & $\begin{array}{l}\text { Spicule content } \\
\left(\mathrm{mg} \mathrm{ml}^{-1}\right. \\
\text { live sponge) }\end{array}$ & $\begin{array}{l}\text { Spicule or } \\
\text { skeleton density } \\
\text { (\% dry wt) }\end{array}$ \\
\hline Chondrilla australiensis & 80 & 5.4 & 5.8 \\
\hline Chondrilla sp. & 100 & 23.0 & 7.3 \\
\hline Clathria pyramida & 410 & 14.8 & 9.4 \\
\hline Callyspongia sp. & 725 & 10.6 & 11.7 \\
\hline Tedania anhelans & 700 & 30.4 & 13.0 \\
\hline Cacospongia sp. ${ }^{\mathrm{a}}$ & na & na & 38.0 \\
\hline \multicolumn{4}{|c|}{ a Whole skeleton (see Fig. 1) } \\
\hline
\end{tabular}

\section{DISCUSSION}

Spicules from 4 of the 5 spiculate sponges we examined reduced grazing activity by the urchin Centrostephanus rodgersii, and 3 of these reduced it significantly. This is the first demonstration that sponge spicules, when assayed in an artificial diet of similar nutritional quality to sponge tissues, deter feeding by sea urchins. Hill \& Hill (2002) suggested that the reason spicules were not effective deterrents in previous feeding trials was because they were not offered in the natural tracts in which they are found in intact sponges. The present study and those of Burns \& Ilan (2003) and Hill et al. (2005) confirm that spicules, even when not presented to predators in natural tracts, are capable of deterring consumers. There is also evidence that spicules presented to predators in their natural orientation may not be effective deterrents (Chanas \& Pawlik 1996), even with foods devoid of measurable protien. Clearly, the importance of natural arrangements of spicules remains poorly resolved and worthy of closer attention.

Importantly, our data questions the notion that spicules must exceed $250 \mu \mathrm{m}$ in length to be effective deterrents (Burns \& Ilan 2003). We found that even microscleres, spicules measuring $<100 \mu \mathrm{m}$ in length, could be effective in deterring urchin feeding. Burns \& Ilan (2003) noted a significant correlation between spicule morphology (length) and their ability to deter predatory wrasses Thalassoma spp. They reported that only sponges with spicule lengths $>250 \mu$ m deterred these fish predators, although the small spherasters of Chondrilla nucula were apparently contaminated with large spicules from another sponge. The size of physical structures has also been shown to deter consumers in terrestrial systems (e.g. Young 1987), but it may not be the only physical means by which a sessile organism defends itself. For example, Bazely et al. (1991) report increases in the number of spines when preda- tors attack brambles, while for sponges, Hill \& Hill (2002) observed increases in the density of spicules following simulated attack. Hence, a combination of the length and number of physical deterrents may provide a much clearer picture of the overall defensive strategy of sessile organisms.

We explored this connection further by plotting the relationship between spicule length $(\mu \mathrm{m})$ and density $\left(\mathrm{mg} \mathrm{ml}^{-1}\right)$ for SE Australian, Caribbean and Red Sea sponges (Fig. 3). The data for the Caribbean sponges should be treated with caution as they were not exposed to their normal predators (Burns \& Ilan 2003). Nevertheless, we did not find support for the prediction that sponges that deterred consumers would possess large or more numerous spicules, or indeed a combination of the two. Those species with particularly large and/or numerous spicules (e.g. Geodia neptuni and Suberites clavatus) did indeed deter predators, but importantly some Australian sponges effectively deterred grazers yet possessed very small spicules in low densities (Chondrilla australiensis). The consistent pattern that we did observe for SE Australian sponges was that those that were effective at deterring urchins from grazing were all encrusting in habit. Skeletal elements from the erect fan, Cacospongia sp. and mound-forming Callyspongia sp. did not

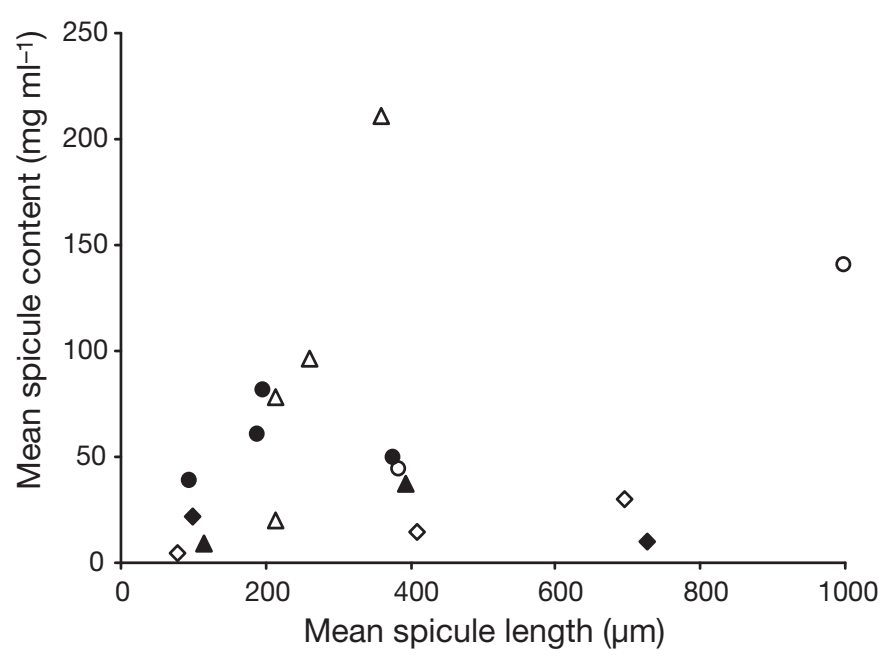

Fig. 3. Relationship between spicule length of the largest spicule type and spicule content for SE Australian (the present study; $\diamond \diamond)$, Caribbean $(\diamond \bullet)$ and Red Sea $(\Delta \mathbf{\Delta})$ sponges. Each point represents a species; those demonstrating statistically significant deterrent effects are represented by open symbols and those that do not by black symbols. Red Sea and Caribbean data from Burns \& Ilan (2003). Only the first feeding trial with Callyspongia sp. is presented 
deter predators, but their growth form may confer protection from invertebrate grazers (Jackson 1977).

Rather than acting directly as deterrents, the presence of spicules may alter the nutritional quality of sponge tissue. Chanas \& Pawlik (1996) rejected this suggestion, arguing that the lowest protein content they measured in Caribbean sponges would need to be lowered a further 3-fold if spicules were to constitute an effective nutritional defense. It is also noteworthy that spicules from the didemnid ascidian examined by Lindquist et al. (1992) were more than double the concentration observed in sponges (approaching $500 \mathrm{mg}$ $\mathrm{ml}^{-1}$ ) but did not deter fish predators. It is striking that the mean spicule content $\left(\mathrm{mg} \mathrm{ml}^{-1}\right.$ live sponge) is more than 4-fold higher for the tropical sponges examined by Burns \& Ilan (2003) relative to the temperate Australian species, although total energy content averages around 2 to $2.5 \mathrm{~kJ} \mathrm{ml}^{-1}$ in all 3 regions. This difference lends support to the notion that spicules do not modify the nutritional quality of the temperate Australian sponges we examined. Nevertheless, it may be difficult to disentangle the relative importance of spicules modifying sponge nutritional quality and the effects of spicule morphology (length), as these variables are frequently positively correlated.

In our feeding trials, large spicules of Callyspongia sp. $(>725 \mu \mathrm{m})$ proved ineffective in deterring urchin grazing. This was unexpected, given findings in other regions. However, the repeat feeding trial with this species was consistent; more of the treatment discs (i.e. containing spicules) were consumed than the controls. We contend that this does not disprove the utility of large spicules as feeding deterrents but may reflect our presentation of spicules in random orientations in the feeding discs rather then the tracts of spicules found in the intact sponge. An alternative explanation is that the deterrent capacity of spicules of Callyspongia sp. was tested in discs with around twice the energy value of the intact sponge; hence, we may have underestimated their defensive capacity in our biossays (Duffy \& Paul 1992).

Our finding that spongin skeleton was ineffective at deterring urchins was consistent with previous work on generalist predators on tropical reefs. We observed urchins simply removing tissue from around the skeleton of Cacospongia sp. without grazing directly on it. Waddell \& Pawlik (2000a) report a similar result for hermit crabs feeding on tissue from around the spiculate spongin skeletons of 2 Caribbean sponges. As with our urchins, the hermit crabs simply removed small pieces of tissue and were unhindered by the presence of the skeleton.

In preliminary trials, we held urchins in captivity for $24 \mathrm{~h}$. However, they did not consistently consume enough of the discs, so that replicates where $<5 \%$ of both discs had been consumed had to be excluded from the analysis, resulting in small sample sizes. Consequently, urchins were maintained in the buckets for 3 to $6 \mathrm{~d}$ prior to their use in a trial. Urchins used in experimental feeding trials in previous studies have been starved for various lengths of time: 36 to $48 \mathrm{~h}$ (Steinberg \& van Altena 1992), 4 d (Ayling 1978) and from 1 to $2 \mathrm{wk}$ (Uriz et al. 1996). It has been argued that starving urchins is not ecologically realistic (Cronin \& Hay 1996). However, we maintain that the animals require time to acclimate following handling and restraint within the plastic containers. Should a lack of food have affected their behaviour in our containers, it would be expected to lead to a decrease in deterrence and hence a conservative test of our hypothesis.

A large literature underscores the important role that secondary metabolites play in the defense of sessile invertebrates, particularly sponges (e.g. Davis et al. 1989, Paul 1992). In a previous study on temperate reef sponges in SE Australia, Wright et al. (1997) demonstrated that organic extracts from 3 of 4 encrusting species collected from the barrens habitat in SE Australia deterred feeding by Centrostephanus rodgersii. Three of those species were represented in the present study. Solvent extracts of Clathria pyramida (Clathria sp. 1 in Wright et al. 1997) and Chondrilla australiensis deterred urchins from grazing at $50 \%$ of their natural concentration (determined volumetrically). Tedania anhelans (misidentified as Pronax sp. in Wright et al. 1997) on the other hand failed to deter urchins when extracts were at $100 \%$ of natural concentration. Our finding that spicular armament in these 3 species provides antifeedent defense raises the possibility that physical and chemical defenses may well interact, contributing to the defensive repertoire employed by these temperate reef sponges. Burns \& Ilan (2003) explored just such an interaction between chemical and physical defense for the Red Sea sponge Crella cyatophora, while Hill et al. (2005) examined the temperate zone sponge Microciona prolifera. They concluded that physical and chemical defenses were indeed interacting in these species. Jones et al. (2005) examined defensive synergies in 8 species of Caribbean sponge; only 2 species showed evidence of synergisms at natural spicule and extract concentrations. They concluded that defensive synergy was not a general rule. An important focus for future work will be to disentangle the relative importance of physical and chemical defenses in sponges and their effectiveness in deterring predators.

Finally, none of the 8 Caribbean sponges examined by Chanas \& Pawlik (1995) and only 1 of the 6 species examined from the Red Sea (Burns \& Ilan 2003) employed both chemical and physical deterrents. In contrast, 2 of the 3 species examined for physical and 
chemical feeding deterrents in SE Australia possessed both (Fig. 2 from Wright et al. 1997). Given the small sample sizes, it may be premature to speculate about disparate defensive strategies in different biogeographical regions. Only with the assessment of additional sessile invertebrate species with a variety of predators in a range of geographical locations will a clearer picture of roles of siliceous or calcareous inclusions in providing physical defense emerge. It is worth noting that wrasses, the organisms of choice in tropical feeding assays, handle food in a different manner to echinoderms; the fish employ a pharyngeal mill, while soft tissue around the Aristotle's lantern in urchins may be particularly susceptible to the lodgement of spicules. It is now clear that sponges use a combination of defensive strategies in temperate and tropical environments (Hill et al. 2005, Jones et al. 2005). It seems likely that we have been underestimating the defensive capacity of these invertebrates (Davis 2007) and this now requires careful reassessment.

Acknowledgements. For assistance in the field and laboratory we thank D. Ward, H. Battam, J. Kinley, J. Dunn, A. Broad, J. Klages and S. Duerr. The protein analysis was completed by I. Tremblay. We are also grateful to K. Benkendorff, M. Gregory, S. Fyfe, J. Himmelman and 3 anonymous reviewers for improving early drafts of this manuscript. M. Ilan kindly provided data for Red Sea sponges for Fig. 3. The Institute for Conservation Biology provided financial support. This represents contribution no. 281 from the Ecology and Genetics group, University of Wollongong.

\section{LITERATURE CITED}

Andrew NL (1993) Spatial heterogeneity, sea urchin grazing, and habitat structure on reefs in temperate Australia. Ecology 74:292-302

Andrew NL, Underwood AJ (1993) Density-dependent foraging in the sea urchin Centrostephanus rodgersii on shallow subtidal reefs in New South Wales, Australia. Mar Ecol Prog Ser 99:89-98

> Ayling AL (1978) The relation of food availability and food preferences to field diet of an echinoid Evechinus chloroticus (Valenciennes). J Exp Mar Biol Ecol 33:223-235

Baker G, Jones LHP, Wardrop ID (1959) Cause of wear in sheeps' teeth. Nature 184:1583-1584

Bakus GJ (1964) The effects of fish grazing on invertebrate evolution in shallow tropical water. Allan Hancock Found Occas Pap 27:1-29

Bazely DR, Myers JH, Silva KB (1991) The response of the number of bramble prickles to herbivory and depressed resource availability. Oikos 61:327-336

Bergquist PR (1978) Sponges. University of California Press, Berkeley, CA

Birenheide R, Amemiya S, Motokawa T (1993) Penetration and storage of sponge spicules in tissues and coelom of spongivorous echinoids. Mar Biol 115:677-683

Bowerbank JS (1864) A monograph of the British Spongiadae. Ray Society, London

Burns E, Ilan M (2003) Comparison of anti-predatory defenses of Red Sea and Caribbean sponges. II. Physical defense.
Mar Ecol Prog Ser 252:115-123

Chanas B, Pawlik JR (1995) Defenses of Caribbean sponges against predatory reef fish. II. Spicules, tissue toughness, and nutritional quality. Mar Ecol Prog Ser 127:195-211

Chanas B, Pawlik JR (1996) Does the skeleton of a sponge provide a defense against predatory reef fish? Oecologia 107:225-231

Cronin G, Hay ME (1996) Susceptibility to herbivores depends on recent history of both plant and animal. Ecology 77:1531-1543

Davis AR (2007) Are we underestimating the defensive capacity of sessile invertebrates? Box 14.1. In: Connell SD, Gillanders BM (eds) Marine ecology. Oxford University Press, Melbourne, p 382

Davis AR, Bremner JB (1999) Potential antifouling natural products from Ascidians: a review. In: Fingerman $M$, Nagabhushanam R, Thompson MF (eds) Recent advances in marine biotechnology, Vol III. Biofilms, bioadhesion, corrosion and biofouling. Science Publishers, Enfield, NH, p 259-308

Davis AR, Targett NM, McConnell OJ, Young CM (1989) Epibiosis of marine algae and benthic invertebrates: natural products chemistry and other mechanisms inhibiting settlement and overgrowth. In: Scheuer PJ (ed) Bioorganic marine chemistry, Vol 3. Springer-Verlag, Berlin, p 85-114

Davis AR, Fyfe SK, Turon X, Uriz MJ (2003) Size matters sometimes: wall height and the structure of subtidal benthic invertebrate assemblages in southeastern Australia and Mediterranean Spain. J Biogeogr 30:1797-1807

> Dayton PK, Robilliard GA, Paine RT, Dayton LB (1974) Biological accommodation in the benthic community at McMurdo Sound, Antarctica. Ecol Monogr 44:105-128

Duffy JE, Paul VJ (1992) Prey nutritional quality and the effectiveness of chemical defenses against tropical reef fishes. Oecologia 90:333-339

> Fletcher WJ (1987) Interactions among subtidal Australian sea urchins, gastropods, and algae: effects of experimental removals. Ecol Monogr 57:89-109

> Harvell CD, Fenical W, Greene CH (1988) Chemical and structural defenses of Caribbean gorgonians (Pseudopterogorgia spp.). I. Development of an in situ feeding assay. Mar Ecol Prog Ser 49:287-294

Hill MS, Hill AL (2002) Morphological plasticity in the tropical sponge Anthosigmella varians: responses to predators and wave energy. Biol Bull (Woods Hole) 202:86-95

> Hill MS, Lopez NA, Young KA (2005) Antipredator defenses in western North Atlantic sponges with evidence of enhanced defense through interactions between spicules and chemicals. Mar Ecol Prog Ser 291:93-102

Hixon MA (1983) Fish grazing and community structure of coral reefs and algae: a synthesis of recent studies. In: Reaka ML (ed) The ecology of deep and shallow coral reefs. Symposia series for undersea research. NOAA/ NURP, Washington, DC, p 79-87

Hooper JNA, Wiedenmayer F (1994) Porifera. In: Wells A (ed) Zoological catalogue of Australia, Vol 12. CSIRO, Melbourne, p 624

Jackson JBC (1977) Competition on marine hard substrata: the adaptive significance of solitary and colonial strategies. Am Nat 111:743-767

Jones LHP, Milne AA (1963) Studies of silica in the oat plant. I. Chemical and physical properties of the silica. Plant Soil 18:207-220

> Jones AC, Blum JE, Pawlik JR (2005) Testing for defensive synergy in Caribbean sponges: bad taste or glass spicules? J Exp Mar Biol Ecol 322:67-81 
Karban R, Myers J (1989) Induced plant responses to herbivory. Annu Rev Ecol Syst 20:331-348

Koh LL, Goh NKC, Chou LM, Tan YW (2000) Chemical and physical defenses of Singapore gorgonians (Octocorallia: Gorgonacea). J Exp Mar Biol Ecol 251:103-115

Lindquist N, Hay ME, Fenical W (1992) Defense of ascidians and their conspicuous larvae: adults vs larval chemical defenses. Ecol Monogr 62:547-568

López-Legentil S, Turon X, Schupp P (2006) Chemical and physical defenses against predators in Cystodytes (Ascidiacea). J Exp Mar Biol Ecol 332:27-36

McClintock JB (1987) Investigation of the relationship be tween invertebrate predation and biochemical composition, energy content, spicule armament and toxicity of benthic sponges at McMurdo Sound, Antarctica. Mar Biol 94:479-487

McNaughton SJ, Tarrants JL, McNaughton MM, Davis RR (1985) Silica as a defense against herbivory and a growth promoter in African grasses. Ecology 66:528-535

Meylan A (1988) Spongivory in hawksbill turtles: a diet of glass. Science 239:393-395

Myers JH, Bazely D (1991) Thorns, spines and prickles: Are they stimulated by herbivory and do they deter herbivores? In: Tallamy D, Raupp M (eds) Herbivore induced phytochemical changes in plants. Wiley, New York, p 325-344

O'Neal W, Pawlik JR (2002) A reappraisal of the chemical and physical defenses of Caribbean gorgonian corals against predatory fishes. Mar Ecol Prog Ser 240:117-126

O'Neill CH, Hodges GM, Riddle PN, Jordan PW, Newman RH, Flood RJ, Toulson EC (1980) A fine fibrous silica contaminant of flour in the high oesophageal cancer area of North-east Iran. Int J Cancer 26:617-628

O'Neill CH, Pan Q, Clarke G, Liu FS and others (1982) Silica fragments from millet bran in mucosa surrounding oesophageal tumours in patients in northern China. Lancet 319:1202-1206

Palumbi SR (1986) How body plans limit acclimation: responses of a demosponge to wave force. Ecology 67:208-214

Paul VJ (ed) (1992) Ecological roles of marine natural products. Comstock Publishing, Ithaca, NY

Editorial responsibility: Joseph Pawlik, Wilmington, North Carolina, USA
Randall JE, Hartman WD (1968) Sponge-feeding fishes of the West Indies. Mar Biol 1:216-225

Sangster AG (1970) Intracellular silica deposition in immature leaves in three species of the Graminae. Ann Bot (Lond) 34:245-257

Smith PK, Krohn RI, Hermanson GT, Mallia AK and others (1985) Measurement of protein using bicinchoninic acid. Anal Biochem 150:76-85

Steinberg PD, van Altena I (1992) Tolerance of marine invertebrate herbivores to brown algal phlorotanins in temperate Australasia. Ecol Monogr 62:189-222

Underwood AJ, Kingsford MJ, Andrew NL (1991) Patterns in shallow subtidal marine assemblages along the coast of New South Wales. Aust J Ecol 6:231-249

Uriz MJ, Turon X, Becerro MA, Galera J (1996) Feeding deterrence in sponges. The role of toxicity, physical defenses, energetic contents, and life-history stage. J Exp Mar Biol Ecol 205:187-204

Uriz MJ, Turon X, Becerro MA, Agell G (2003) Siliceous spicules and skeleton frameworks in sponges: origin, diversity, ultrastructural patterns and biological functions. Microsc Res Tech 62:279-299

- Van Alstyne KL, Paul VJ (1992) Chemical and structural defenses in the sea fan Gorgonia ventalina: effects against generalist and specialist predators. Coral Reefs 11: 155-159

Waddell B, Pawlik JR (2000a) Defenses of Caribbean sponges against invertebrate predators. I. Assays with hermit crabs. Mar Ecol Prog Ser 195:125-132

Waddell B, Pawlik JR (2000b) Defenses of Caribbean sponges against invertebrate predators. II. Assays with sea stars. Mar Ecol Prog Ser 195:133-144

Whiting F, Connell R, Forman SA (1958) Silica urolithiasis in beef cattle. Can J Comp Med Vet Sci 22:332-337

Wright JT, Benkendorff K, Davis AR (1997) Habitat associated differences in temperate sponge assemblages: the importance of chemical defence. J Exp Mar Biol Ecol 213: $199-213$

Young TP (1987) Herbivory induces increased thorn length in Acacia depanolobium. Oecologia 71:436-438

Submitted: April 21, 2008; Accepted: August 5, 2008

Proofs received from author(s): November 19, 2008 